TILTAI, 2015, 3, 129-139, ISSN 1392-3137 (Print), ISSN 2351-6569 (Online)

\title{
INDIVIDUAL APPROACH AND DIFFERENTIATION AS MEANS FOR LEARNING OPTIMIZATION AT PRIMARY CLASSES OF SPECIAL NEEDS SCHOOLS
}

\author{
Svitlana Yakovleva \\ Kherson State University (Ukraine)
}

\begin{abstract}
The article reveals the content of individual and differentiated approaches to teaching of primary school children with mental development disorders. Learning objectives and the ways to achieve them. The forms of activity organization are determined to develop children's abilities to acquire and apply skills. Appropriateness of programmed learning as a part of the differentiated approach is analyzed to educate children with mental development disorders. Practical aspects of individual approach and differentiation are presented with the example of teaching of primary school-children at a special needs school.

KEY WORDS: individual approach, differentiation, programmed learning, schoolchildren with mental development disorders, learning activities.
\end{abstract}

\begin{abstract}
Anotacija
Straipsnis atskleidžia skirtingų požiūrių i pradinių mokyklų vaikų, turinčių psichikos vystymosi sutrikimų, mokymo turinio raišką. Pristatomi mokymosi tikslai ir būdai, kaip jų siekti. Aprašomos veiklos organizavimo formos, padedančios įtvirtinti vaikų ịgūdžius. Analizuojamas programinio mokymo tinkamumas, kaip dalis diferencijuoto požiūrio, ugdant vaikus su protiniais sutrikimais. Praktiniai individualaus požiūrio ir diferenciacijos požiūriai pristatomi kaip pavyzdžiai mokantis specialiụjų poreikių turinčių vaikų pradinejje mokykloje.

PAGRINDINIAI ŽODŽIAI: individualus požiūris, diferenciacija, programinis mokymasis, psichikos vystymosi sutrikimų turintys moksleiviai, mokymosi veikla.
\end{abstract}

DOI: http://dx.doi.org/10.15181/tbb.v72i3.1171

\section{Introduction}

The main steps of differentiated learning technique are determined by the requirements developed in pedagogical theory and practice and related to educational techniques in general and to the tiered organization of schoolchildren education in particular (Ananiev, 1960). They can include:

- Defining of a clear system of learning objectives.

- Determination of an initial state of child's learning abilities, determination of typological groups.

- Construction of a learning cycle, creation of the impact program taking into account transition states of the children from each typological group. 
- Implementation of the planned tasks, organization of children's learning activities.

Obtaining of information on activities, evaluation of current results.

- Clarification of learning objectives, making of necessary adjustments.

- The final evaluation of learning outcomes.

- Cycle repeat without changes or with correction (Бондар, 1999).

Each of these steps is a subject to technical description. For example, determination of learning objectives should guide schoolchildren onto main issues which that they need to learn during mastering of a chosen topic or chapter. Learning objectives can be specified in different ways: in course material; by teacher's work; through internal processes of child development; through child's activities. A teacher defines the criteria for achieving an objectives to make them fully diagnostic. He / she also understands those goals that are put forward for all schoolchildren so they can effectively acquire knowledge and skills according to their learning abilities. Typological groups are defined usually after introduction of new material to children and its initial consolidation. This division into groups should not be permanent and it allows children's movement from one group to another.

Impact programs for children in each typological group are defined on the base of the following requirements: knowledge have to be acquired by schoolchildren in a clear systematic manner; it is necessary to foresee the difficulties that children can encounter during study of different themes; to create conditions for active mastering of knowledge and skills; to promote children's development; to organize children's communication and cooperation; to provide the necessary pedagogical conditions (Гончаров, 1996).

The following points are defined for schoolchildren of each typological group:

- knowledge complexes (systems) that can ensure consistent, systematic learning, support gradual increase in complexity, creative mastery of knowledge, children's activities;

- forms of work organization (frontal, group, pair, individual types of work);

- an extent and nature of educational assistance during task solving.

Changing of work organization forms and the extent of educational assistance can help create conditions for positive motivation, form children's ability for independent use of acquired knowledge and skills.

Teaching material is divided into separate parts, didactic materials are selected or developed, methods to control and correct schoolchildren are defined.

A teacher can get information on learning course through feedback that must meet the following criteria: sufficient, true, timely, operation-by-operation. Feedback tools include teachers' questions to schoolchildren and vice versa, tasks for control. The feedback results, received after studying a certain topic, determine the 
methods for further learning activities of the schoolchildren of each typological group.

The objectives of corrective work at tiered organization of schoolchildren's, as I. F. Markovska (Марковская, 1995) thinks, learning activities are:

- correction of management components;

- correction of certain personal characteristics of schoolchildren.

During the correction step, the following types of management can be performed: reduction of task volumes and statements, their simplification or complication; increase of the time to do the task; replacement of the in-pair learning form with frontal one or individual learning with group or pair forms; introduction of additional tasks or removal of some tasks of a certain type; extension of assistance during solving of more complex tasks; identification of new types of assistance and so on. Certain personal and etiological characteristics of schoolchildren that are indicators of their educational abilities are also can be corrected.

The rapid development of information technologies and their application in education provide new opportunities for expansion and renovation of learned topic contents, deepen pupils' educational base with graphical competence. Therefore, the problems of graphical competence development at technical drawing lessons become highly important.

Presenting information as graphic dependencies is being used increasingly today, because such presentation is the most economic, illustrative and meaningful one. Graphic presentations of information are used in different fields of visual communication to facilitate the processes of thinking, imagination, to speed up task solutions. Pictures, diagrams, drawings are compact, intensive tools by which thoughts are expressed as graphic statements. Examining a "graphic competence" concept from the point of view of pedagogy and teaching methods, we distinguish two aspects of schoolchildren's graphic competence: an object competence in the form of graphic knowledge and a subjective one that is manifested through schoolchildren's graphic activities.

\section{On the problem of mental activity formation at special needs schools}

One of the main problems of special needs schools is formation of adequately independent and active mental activity of the children with mental development disorders. These qualities influence largely on the dynamics of personal development of such child, their adaptive abilities during socialization.

One of the means for increasing activity and autonomy during the process of the education is to use algorithmic elements in learning tasks, i.e. elements of programmable multilevel learning. Programmed learning, according to some 
authors (Бex, 1999 and others) allows teachers to efficiently combine group and individual work with each child, providing, within a single learning framework, various degrees of depth and different amounts of learning material, depending on schoolchild's abilities. This is achieved through the selection of tasks and exercises of varying difficulty. In addition, in the course of independent work of a programmable nature, it is possible to implement the differentiated approach in education.

Namely, the possibility to create the best feedback and to implement the individual and differentiated approaches is the cause of attention attraction to programmable tasks as a method of educational work with children with cognitive development disorders.

Using of programmable tasks in education of children with mental development disorders have not yet received detailed methodological developments in the literature, but studies of several authors (Коберник, Синев, 1984) convince teachers of special needs schools to search programmable tasks with a variety of content and methodical equipment that contribute to solution of various didactic problems that appear in education of this category of children. These studies offer programmable tasks that can be useful in order to perform a current control of teaching the children with mental development disorders, but the possibility of their use as tools for learning and consolidation of educational material has not been examined.

The programmable tasks for different educational subjects in education of children with intellectual incapacities must meet the following requirements:

- to include a specific educational task;

- to include a fairly complete (specific or generalized - for different groups of children) concentrating basis for mental activities;

- to correspond meaningfully and methodically to a children's preparedness level, to peculiarities of their cognitive activities, so the task shall be located in a zone of proximal development of a particular child;

- to have operational techniques in its content that provide feedback.

In the practice, it is offered to use examples of various (as for their content and solution) didactical programmed tasks at nature study lessons in special needs schools. In our view, these tasks not only contribute to the organization of operational feedback of learning, but also include a concentrating basis for mental activities that contribute to formation of schoolchildren knowledge and skills, increase their activity and autonomy in educational activities at the stage of consolidation and at the stage of mastering new material. These tasks are complementary. Some of them contain concentrating basis for mental activities and are aimed at knowledge acquisition. Others contain material that reinforces knowledge and forms practical skills of schoolchildren. 
Multilevel tasks can be used at different stages of a lesson and thus have different educational objectives. Thus, at the stage of mastering new knowledge, a teacher uses programmable multilevel tasks in a group to work with children who saved in a large degree orientation processes and are capable to make independent generalizations of low complexity (the $1^{\text {st }}$ group of schoolchildren). The management of cognitive activities of such schoolchildren with the algorithms of learning and mental activities promotes independence and activity of thinking, forms a reflexive-personal component of learning.

\section{A special attitude to schoolchildren with more severe underdevelopment}

The schoolchildren with more severe underdevelopment of orienting activities and mental operations, the so-called middle group (the $2^{\text {nd }}$ group of schoolchildren) cannot work with programmable tasks at the stage of mastering the knowledge, so they only listen to the title of the topic and acquire a reasoning logic that reveal relationships or properties of a studied object, phenomenon. However, at the stage of knowledge consolidation, this work is feasible for them. They are able to formulate answers to task questions or find correct answers from a set of answers.

Children with severe underdevelopment of cognitive processes, so-called weak group (the $3^{\text {rd }}$ group of schoolchildren) can use such programmable tasks only at the stage of consolidation and repetition of the material by reading questions and the corresponding answers. Didactic tasks for education of mentally retarded children of this group with programmable tasks foresee mastering of logic reasoning, formation of the ability to establish simple logical relationships in educational material, developing of the ability to elemental abstraction.

Thus, the use of such programmable tasks in the learning process of special needs schools helps stage-by-stage formation of schoolchildren's mental actions, development of analytical and synthetic thought processes, the ability to generalize and abstract, and at the same time takes into account individual and typological features of children's cognitive activities. In addition, development of cognitive and learning activities takes palace, in general, at greater activity and independence manifested by schoolchildren during learning.

\section{Experimental research}

Practical aspects of individual approach and differentiation of primary school children in special needs schools were studied at the Kherson special school No 1 (2-3 classes). 
Peculiarities of teaching were estimated in general as well as teacher's use of some elements of individual approach and differentiation at learning.

A teacher can use in class a variety of methods in class. This is one of the hallmarks of lessons as the basic organizational form of learning in primary special needs schools. The variety of methods and techniques is especially important in primary school, when transition to a 45 minute lesson is quite difficult for children.

A child in a class thinks about learned material, makes observations, performs exercises, practical work, answers to teacher's questions, etc. Step by step, primary school children, under the guidance of a special education teacher, learn to work independently, develop cognitive abilities, arbitrary mental processes.

Independent work takes a leading place as a part of a class-work. According to the primary school curricula, it includes reading, task solving, practical work, observations. Developing of independent work skills in a classroom helps schoolchildren master specific techniques of homework.

A teacher works with the entire children group using one of class-task forms of educational work organization. Working in a group improves children's learning. By listening to other classmates' answers, answering him / herself, adding other children's answers, a child can learn lessons more deeply and consciously. Individual work can also be performed in a form of cooperation of several children. So, frontal and individual forms of work are used at lessons.

The individual approach to a child in a classroom means that a teacher, knowing the characteristics of each child, uses appropriate instructional techniques in working with schoolchildren. The basis of the individual approach is systematic and comprehensive study of schoolchildren by their teacher. A variety of methods is used for this purpose. The main technique among them is observation of schoolchildren in their classroom and during extracurricular activities. Knowing individual characteristics of his / her schoolchildren, the teacher is able to achieve a high level of correctional and educational work that allows him / her to compensate or diminish developmental disorders that the children are suffering.

Teachers pay particular attention to analysis of the data about the nature of mental deficiency of each child, its causes, the main features of child's behaviour, interests, inclinations, attention, perception of visual and verbal material, knowledge quality and overall development. Moreover, a teacher takes into account the state of vision, hearing; language development, motor coordination. All these indicators form the basis for optimal planning of the lessons, definition of their complexity and volume of tasks. It should be taken into account that difficult tasks are not necessary to be removed from material selected for lessons. The tasks should be reasonably difficult, bearing in mind that the individual and differentiated approach to schoolchildren should not be reduced to a passive adaptation to them, but 
such approach means finding of the most appropriate means of children's involving into frontal class work.

\section{Implementation of the differentiated approach to teaching in special needs schools}

Different extent of assistance to children is used widely as a technique of individual learning. So, a teacher can offer writing along letter outlines or with reference points in children's notebooks for those children who experience difficulty in writing letters or numbers. Children who cannot perform the task in accordance with an oral instruction, because of they have difficulties in memorize it, shall have an appropriate visual help. Tasks for children with the slow pace of learning are measured and regulated especially attentively with attempts to accelerate gradually their pace otherwise such children cannot be able to work together with all group and this may have a negative effects of them.

The right approaches to the analysis and evaluation of children's activities has considerable importance at individual work with schoolchildren at special needs schools. A teacher should always be focused on children's positive qualities, find such forms of their evaluation that would stimulate their work. This undoubtedly has a positive influence on child's activities, prevents conflict, when a child refuses to work in a classroom or behaves badly, etc.

Implementation of a differentiated approach to teaching in special needs schools is based, at present, on the fact that several groups of schoolchildren characterized by different typological features can be determined at each class. However, in practice, the differentiation is made only within the two levels at class formation on the base of learning abilities of schoolchildren. This allows teachers to organise differentiated learning within one school without redeveloping of the established educational system. It is necessary only to form classes and to determine groups in the formed classes if schoolchildren have not been examined previously.

At differentiated learning, children for the $1^{\text {st }}$ class are grouped in classes not according to their age, but depending on development of their cognitive functions and abilities. At school, depending on the existing contingent, two parallel classes are formed with children of about the same level of development, or two parallel groups in one class are organized and children with very different cognitive abilities are separated into different groups.

Learning in each class or group is carried out with special educational programs. The scope and content of educational material for children with higher cognitive abilities meet the basic, the requirements of existing educational programs. 
So, a greater independence of children is ensured. Schoolchildren with lower cognitive abilities should acquire smaller volume of knowledge according to curriculum for special schools.

Classes formed of children with better cognitive abilities form the first department, and classes of children with lower cognitive abilities make the second department. Regional psychological, medical and educational centres determine to which department a child will be sent entering the $1^{\text {st }}$ class.

To avoid errors during enrolment of children into parallel classes at the first year of education, in depth diagnosing of children is performed in the first educational month, conclusions made by regional psychological, medical and educational centres concerning cognitive ability development are specified, factual data needed for reasoned placement of children into different classes are gathered. On the base of diagnosing performed during the first educational month, the schoolchildren are enrolled into classes for differentiated learning. Proposals for such enrolment are prepared by the school medical-educational committee consisting of teachers and other educators and a school physician who directly participated in children diagnosing. Class composition defined at the beginning of the year is basic. These classes teach language and literary reading, math, nature study, geography, history, painting, singing, handicrafts during the whole period of study with different programs.

To test in practice some approaches to learning individualization, we have developed cards with multilevel tasks of nature study as well as lessons for the $3^{\text {rd }}$ class in mathematics and Russian language with elements of the differentiated and individual approaches.

\section{Aim of the empirical research}

The research was performed in Kherson special secondary school No 1, in the third class consisting of 14 children, 5 of which have weaker mentality and 6 are better, and in the $2^{\text {nd }}$ class, which includs 7 children ( 3 with weaker and 4 with better cognitive abilities). At research scheduling, we took into account individual abilities of the children and an average group level of development. Thus, at task solving, the weaker children worked on cards with easier tasks, and better ones did more difficult cards. In class, simultaneously with the main educational material, already studied topics were repeated, the work was carried out to develop cognitive interest, speech, thinking abilities, links with real life were established (information on different professions, etc.). The course material was repeated when it was necessary for its better mastering. Children who are slow learnes obtained smaller volume of the tasks. The most important points of the lesson were played. 
The analysis of the children's work in the proposed differentiated and individualized conditions showed an improved positive attitude to the tasks and better mastering of the topic. This confirms the potential of these approaches and the necessity of further development of the appropriate methodological support that can be used in the practice of special schools.

According to literature data, mentally retarded children with defects of the central nervous system have abnormalities in development of some systems and functions needed for graphic task performance (graphic dictation, labyrinths, interweaving lines etc.), they have slowness and tension of movements, difficulty in switching from one movement to another, inaccuracy of movements. This causes poor performance of arbitrary regulation of these children and their quick fatigue.

The volitional impulse weakness of mentally retarded children results in insufficient active involvement of these children into their work. This causes their passivity and inability to mobilize their activity. Periods of tension are followed by periods of passivity, finding their expression in objective quantitative and qualitative changes in the work results.

The comparative study of static tension of right and left limb muscles of mentally retarded schoolchildren confirms their weakness. Particular attention was paid to finger movements. Slow and tensed movements, difficulty in switching from one movement to another are related with low mobility of nervous processes, and movement inaccuracy is caused by absence of differentiation and excessive irradiation.

The "Labyrinth" method used in diagnosing of individual learning difficulties of primary school children in special needs school revealed that the problem of graphic skill formation is related not only with poor attention, but with poor hand readness to writing. The "Labyrinth" method includes the following equipment: 5-6 examples of labyrinths, a pencil, a stopwatch.

Several sheets of paper with drawn labyrinths of increasing difficulty are given to a child. He / she must quickly find a way out of each by following of some rules: not to lose pencils' contact with the paper; to start pencil work immediately without labyrinth examining with his / her eyes before each new task; not to touch or cross labyrinth lines (each touching is a mistake as well as each back turn). A child receives 5-6 different labyrinths. Time limit for one 1 labyrinth is $1 \mathrm{~min}$., maximum permissible errors are 5. Evaluation is made by the following criteria: without errors means a high level, 1 error in 1 labyrinth is an average level, more than 2 errors in each labyrinth is low one.

Even in the first stage of the study it was clear that schoolchildren of the 3rd class coped better with the "Labyrinth" method $(60.83 \%)$, while the $2^{\text {nd }}$-class children achieved positive results in $54.29 \%$ of cases. This is because the $3^{\text {rd }}$-class 
children have better developed graphic skills thanks to their training activities (tab. $1,2)$. While graphic skills of the $2^{\text {nd }}$-class children are at an early level. However, despite the above mentioned, the $2^{\text {nd }}$-class children at the second phase of the study showed better results compared to the first phase of the study $\left(54.29 \%\right.$ in the $2^{\text {nd }}$ quarter of an academic year; and $60.71 \%$ in the $3^{\text {rd }}$ quarter).

Table 1. The study of graphic skill development and the arbitraryregulation level of children with intellectual disabilities (the $2^{\text {nd }}$ class)

\begin{tabular}{|l|l|l|l|}
\hline \multirow{2}{*}{ No } & \multirow{2}{*}{ Name } & \multicolumn{2}{|c|}{ "Labyrinth" method } \\
\cline { 3 - 4 } & & II quarter, \% & III quarter, \% \\
\hline 1. & B-nR & 35 & 30 \\
\hline 2. & K-aU & 60 & 70 \\
\hline 3. & A-yS & 30 & 35 \\
\hline 4. & P-oV & 40 & 60 \\
\hline 5. & S-kV & 70 & 70 \\
\hline 6. & S-vP & 70 & 75 \\
\hline 7. & S-oM & 75 & 80 \\
\hline & Average & 54.29 & 60.71 \\
\hline
\end{tabular}

Table 2. The study of graphic skill development and the arbitrary regulation level of children with intellectual disabilities (the 3rd class)

\begin{tabular}{|c|l|c|c|}
\hline \multirow{2}{*}{ No } & \multicolumn{2}{|c|}{ Name } & \multicolumn{2}{|c|}{ "Labyrinth" method } \\
\cline { 3 - 4 } & & II quarter, \% & III quarter, \% \\
\hline 1. & B-yV & 80 & 80 \\
\hline 2. & B-tYu & 75 & 80 \\
\hline 3. & D-aYe & 35 & 35 \\
\hline 4. & I-oD & 35 & 35 \\
\hline 5. & K-aO & 70 & 75 \\
\hline 6. & B-yV & 80 & 80 \\
\hline 7. & B-tYu & 75 & 80 \\
\hline 8. & K-aV & 60 & 80 \\
\hline 9. & M-vP & 60 & 65 \\
\hline 10. & M-aL & 65 & 70 \\
\hline 11. & O-vO & 65 & 80 \\
\hline 12. & P-khI & 30 & 35 \\
\hline 13. & Ts-kB & 75 & 80 \\
\hline 14. & K-kI & 80 & 80 \\
\hline & Average & 60.8 & 66.25 \\
\hline
\end{tabular}


The obtained experimental data has not only theoretical interest, but also practical importance because it offers a solution for the discussed problem that is a part of a more general problem - correction of shortcomings and individual learning difficulties of mentally retarded children.

The quantitative data obtained based on these methods and its analysis make possible to reveal information about the pedagogical process at the level of objective laws.

\section{Conclusions}

The applied method is a part of a complex study of learning success of children with intellectual disabilities and is related to the nature of the conducted study, with comprehensive examination of the above problems - improvement of the educational process in special needs schools. Besides this, it is important to examine memory, attention, thinking abilities, to perform psychophysiological diagnosis of neurophysiologic systems at an early stage of development. Such study will reflect a comprehensive approach to defining children's readiness for learning and will allow a special education teacher to support schoolchildren's performance at an optimum level and thus to increase learning effectiveness, to successfully solve correctional problems, to make a propaedeutic preparation for the next stage of learning activities of primary school children.

Received 20150912

Approved for publishing 20151005

\section{References}

Ананьев, Б. Г. (1960). Развитие детей в процессе начального обучения и воспитания. Проблемь обучения и воспитания в начальной школе. Москва: Учпедгиз.

Бех, І. (1999). Особистісно-зорієнтоване виховання: шляхи реалізації. Рідна школа 12: 13-17.

Бондар, В. (1999). Основні напрямки та перспективи розвитку дефектологічної науки в Україні. Дефектологія 3: $2-7$.

Гончаров, О. А., Новикова, Г. Р., Шалимов, В. Ф. (1996). Нейропсихологическое исследование высших психических процессов у успевающих учеников начальных классов средней школы. Дефектология 6.

Коберник, Г. Н., Синев, В. Н. (1984). Введение в специальность “Дефектология”. Киев: Вища школа, $144 \mathrm{c.}$

Лебединский, В. В. (1985). Нарушения психического развития у детей. Изд. МГУ.

Марковская, И. Ф. (1995). Задержка психического развития. Клиническая и нейропсихологическая диагностика. Москва.

Махмутов, М. И. (1974). Об индивидуализации обучения. Народное образование 2: 43-49. 
